\title{
A Modified Fluorimetric Method for Determination of Hydrogen Peroxide Using Homovanillic Acid Oxidation Principle
}

\author{
Biswaranjan Paital ${ }^{1,2}$ \\ ${ }^{1}$ Biochemistry Unit, Department of Zoology and Biotechnology, Utkal University, Bhubaneswar 751004, India \\ ${ }^{2}$ Department of Molecular Reproduction, Development and Genetics, Indian Institute of Science, Bangalore 560012, India \\ Correspondence should be addressed to Biswaranjan Paital; biswaranjanpaital@gmail.com
}

Received 21 February 2014; Revised 11 April 2014; Accepted 11 April 2014; Published 19 May 2014

Academic Editor: Vani Nilakantan

Copyright (c) 2014 Biswaranjan Paital. This is an open access article distributed under the Creative Commons Attribution License, which permits unrestricted use, distribution, and reproduction in any medium, provided the original work is properly cited.

\begin{abstract}
Hydrogen peroxide $\left(\mathrm{H}_{2} \mathrm{O}_{2}\right)$ level in biological samples is used as an important index in various studies. Quantification of $\mathrm{H}_{2} \mathrm{O}_{2}$ level in tissue fractions in presence of $\mathrm{H}_{2} \mathrm{O}_{2}$ metabolizing enzymes may always provide an incorrect result. A modification is proposed for the spectrofluorimetric determination of $\mathrm{H}_{2} \mathrm{O}_{2}$ in homovanillic acid (HVA) oxidation method. The modification was included to precipitate biological samples with cold trichloroacetic acid (TCA, $5 \% \mathrm{w} / \mathrm{v}$ ) followed by its neutralization with $\mathrm{K}_{2} \mathrm{HPO}_{4}$ before the fluorimetric estimation of $\mathrm{H}_{2} \mathrm{O}_{2}$ is performed. TCA was used to precipitate the protein portions contained in the tissue fractions. After employing the above modification, it was observed that $\mathrm{H}_{2} \mathrm{O}_{2}$ content in tissue samples was $\geq 2$ fold higher than the content observed in unmodified method. Minimum $2 \mathrm{~h}$ incubation of samples in reaction mixture was required for completion of the reaction. The stability of the HVA dimer as reaction product was found to be $>12 \mathrm{~h}$. The method was validated by using known concentrations of $\mathrm{H}_{2} \mathrm{O}_{2}$ and catalase enzyme that quenches $\mathrm{H}_{2} \mathrm{O}_{2}$ as substrate. This method can be used efficiently to determine more accurate tissue $\mathrm{H}_{2} \mathrm{O}_{2}$ level without using internal standard and multiple samples can be processed at a time with additional low cost reagents such as TCA and $\mathrm{K}_{2} \mathrm{HPO}_{4}$.
\end{abstract}

\section{Introduction}

Hydrogen peroxide $\left(\mathrm{H}_{2} \mathrm{O}_{2}\right)$ is a major toxic byproduct of oxygen metabolism in both animals and plants. Its level therefore is used as a major biomarker in multiple investigations [1]. $\mathrm{H}_{2} \mathrm{O}_{2}$ reacts with superoxide radicals in Haber-Weiss or Fenton reaction and becomes the precursor for production of the highly toxic hydroxyl radical. $\mathrm{H}_{2} \mathrm{O}_{2}$ is also produced in other enzymatic reactions. It is toxic to the living cells in the range of $10-100 \mu \mathrm{M}[2,3]$. In context dependent manner, $\mathrm{H}_{2} \mathrm{O}_{2}$ level in tissues is used to monitor the effect(s) of various pharmacological and other substances for determining free radical generation or free radical scavenging activity [4]. $\mathrm{H}_{2} \mathrm{O}_{2}$ level is also correlated with several enzyme assays or levels such as superoxide dismutase (SOD), catalase (CAT), horse radish peroxidase (HRP), and lipoxygenase (LIP) which are involved in metabolism of $\mathrm{H}_{2} \mathrm{O}_{2}[5,6]$. Apart from these enzymes, xanthine oxidase, urate oxidase, and $\mathrm{D}$ amino oxidase are also responsible for generating $\mathrm{H}_{2} \mathrm{O}_{2}$ in vivo [2]. Therefore, accurate measurement of $\mathrm{H}_{2} \mathrm{O}_{2}$ in tissues is important to determine its ecotoxic, physiological or other relevance(s) [7].

Although modern techniques such as flow cytometry, confocal microscopy and spin trapping methods are available to quantify reactive oxygen species in intact cell samples, biochemical quantification of $\mathrm{H}_{2} \mathrm{O}_{2}$ in tissue fractions is still used in many laboratories across the world [8]. However, the presence of enzymes such as SOD, CAT, LIP, HRP, and other peroxidases and oxidases in biological samples especially in tissue fractions may have a lot of interference during biochemical quantification of $\mathrm{H}_{2} \mathrm{O}_{2}$ [9]. Such enzymes can metabolize $\mathrm{H}_{2} \mathrm{O}_{2}$ during homogenization and centrifugation and during the time of incubation of samples in assay mixture for $\mathrm{H}_{2} \mathrm{O}_{2}$ estimation. Differential concentrations or activities of the above interfering enzymes in the tissue homogenate/lysate may lead to inaccurate $\mathrm{H}_{2} \mathrm{O}_{2}$ quantification. Most of the times, use of an internal standard is suggested to measure the exact tissue $\mathrm{H}_{2} \mathrm{O}_{2}$ content. However, internal standard cannot minimize the error when the interfering agents such as CAT and SOD are in highly variable 
quantities in samples [10]. Theoretically, it seems that the accurate value of $\mathrm{H}_{2} \mathrm{O}_{2}$ cannot be measured in tissue fractions when it contains its catabolizing enzyme, that is, CAT, having high Km value.

Using different substrates such as ferric-xylenol orange, homovanillic acid (HVA), scopoletin, $p$-hydroxyphenylacetic acid, $p$-hydroxyphenylpropionic acid, and tyramine, different biochemical methods are proposed to determine $\mathrm{H}_{2} \mathrm{O}_{2}$ content in tissues $[4,11,12]$. However, HVA-HRP system is widely used due to the stability of its fluorescent product (HVA dimer) being more than others such as scopoletin method [4]. Nevertheless, none of the biochemical methods describe any modification to remove $\mathrm{H}_{2} \mathrm{O}_{2}$ metabolizing enzymes from tissue fractions prior to $\mathrm{H}_{2} \mathrm{O}_{2}$ quantification. During our investigation on mud crabs, we encountered a similar problem to quantify $\mathrm{H}_{2} \mathrm{O}_{2}$ [13]. For the first time, a modified method is reported to estimate more accurate $\mathrm{H}_{2} \mathrm{O}_{2}$ content in biological samples. To achieve the objective, tissue homogenates were precipitated with trichloroacetic acid (TCA, 5\% w/v, which precipitates proteins) and then were neutralized with $\mathrm{K}_{2} \mathrm{HPO}_{4}$ followed by $\mathrm{H}_{2} \mathrm{O}_{2}$ quantification. The method was validated using known concentrations of CAT and $\mathrm{H}_{2} \mathrm{O}_{2}$. Using this modification, multiple samples at a time can be processed to determine more accurate tissue $\mathrm{H}_{2} \mathrm{O}_{2}$ level with additional low cost reagents such as TCA and $\mathrm{K}_{2} \mathrm{HPO}_{4}$. Secondly, the final reaction product can be measured conveniently within $12 \mathrm{~h}$ without any significant loss of the fluorescent value.

\section{Materials and Methods}

2.1. Chemicals. Reagents from Sigma Chemical Company, USA, such as HRP, HVA (4-hydroxy-3-methoxyphenylacetic acid), tris base, and SOD were procured locally. TCA, $\mathrm{K}_{2} \mathrm{HPO}_{4}$ and $\mathrm{KH}_{2} \mathrm{PO}_{4}$ were purchased from SISCO Research Laboratory, Mumbai, India. $\mathrm{H}_{2} \mathrm{O}_{2}$ was obtained from SD Fine Chemicals, Mumbai, India. All other chemicals used were of the analytical grades.

2.2. Instrumentation. All fluorescence studies were performed at $25^{\circ} \mathrm{C}$ with a spectrofluorimeter (Hitachi, Model F 2500, Japan) using $1 \mathrm{~cm}^{2}$ quartz cuvette. Instrument specifications during measurements were $5 \mathrm{~nm}$ for both extinction and emission slit widths and 400 PMT voltages and $315 \mathrm{~nm}$ and $425 \mathrm{~nm}$ for extinction and emission wave lengths, respectively. A Varian CARRY $100 \mathrm{UV}$ Visible spectrophotometer was used to quantify $\mathrm{H}_{2} \mathrm{O}_{2}$ at $340 \mathrm{~nm}$ wave length and for spectral analysis.

2.3. Principle and Procedure. The assay was based on $\mathrm{H}_{2} \mathrm{O}_{2}$ and HRP mediated oxidation of HVA (nonfluorescent) for the production of biphenyl HVA dimer which is fluorescent in nature. The HVA dimer is produced by a covalent bond formed by demolishing the methoxy group of the carbon atom of one HVA molecule at $3^{\prime}$ position with the carbon molecule at $5^{\prime}$ position of the other HVA monomer (Figure 1). The specificity of the assay is described elsewhere [14]. However, the spectral change that takes place after and before the reaction was also checked to confirm the HRP mediated oxidation of HVA by $\mathrm{H}_{2} \mathrm{O}_{2}$ and HRP system.
Reaction mixture for the calibration curve of $\mathrm{H}_{2} \mathrm{O}_{2}$ contained $1.4 \mathrm{~mL}$ of $25 \mathrm{mM}$ phosphate buffer $\mathrm{pH} 7.6$ (PB) with $0.2 \mathrm{~mL} \mathrm{HRP}\left(0.1 \mathrm{U} \mathrm{mL}^{-1}\right)$ and $0.2 \mathrm{~mL} \mathrm{HVA}(125 \mu \mathrm{M})$. Reaction was started with addition of $0.2 \mathrm{~mL}$ of tissue sample or $\mathrm{H}_{2} \mathrm{O}_{2}$ of required concentration into the reaction mixture. Similarly, appropriate blanks $\left[\left(-\mathrm{H}_{2} \mathrm{O}_{2}+\mathrm{HVA}+\mathrm{HRP}\right)\right.$, $\left(+\mathrm{H}_{2} \mathrm{O}_{2}+\mathrm{HVA}-\mathrm{HRP}\right)$ and $\left.\left(+\mathrm{H}_{2} \mathrm{O}_{2}-\mathrm{HVA}+\mathrm{HRP}\right)\right]$ were run to check any background fluorescence of the reaction mixtures. Time kinetics was performed to determine the optimum time period for completion of the reaction at which all the $\mathrm{H}_{2} \mathrm{O}_{2}$ molecules were supposed to consume by the reaction system. Since the aim of the experiment was to precipitate the tissue samples with TCA, therefore, the required concentration of $\mathrm{H}_{2} \mathrm{O}_{2}$ was precipitated in TCA (5\%, $\mathrm{w} / \mathrm{v})$ and then was neutralized with $6 \mathrm{M} \mathrm{K}_{2} \mathrm{HPO}_{4}(3.2 \mathrm{~mL}$ $6 \mathrm{M} \mathrm{K}_{2} \mathrm{HPO}_{4}$ with $15 \mathrm{~mL} \mathrm{H}_{2} \mathrm{O}_{2}$ in 5\% TCA) to keep the $\mathrm{pH}$ of the mixture within $7.50 \pm 0.04$. Then the fluorescence of the above TCA treated $\mathrm{H}_{2} \mathrm{O}_{2}$ was determined. $\mathrm{H}_{2} \mathrm{O}_{2}$ was also incubated with CAT enzyme (5-20 U) for different time periods $(5-20 \mathrm{~min})$ to confirm the role of $\mathrm{H}_{2} \mathrm{O}_{2}$ in the reaction system. After incubation with or without CAT, $\mathrm{H}_{2} \mathrm{O}_{2}$ samples were precipitated with TCA (5\%) and then neutralized with required volume of $\mathrm{K}_{2} \mathrm{HPO}_{4}$ to keep the $\mathrm{pH} \sim 7.5$. The reaction product of HVA dimer in both TCA treated and nontreated $\mathrm{H}_{2} \mathrm{O}_{2}$ samples was kept for different time periods $(2-60 \mathrm{~h})$ to check the stability of the HVA dimer product. Finally, the method was employed in light dependent superoxide generating system. The above was done to check $\mathrm{H}_{2} \mathrm{O}_{2}$ content by incubating the mixture with SOD enzyme which coverts superoxide anions to $\mathrm{H}_{2} \mathrm{O}_{2}$. Both tris and phosphate buffers were used to study the effects of buffers on the assay system. And there was no significant change in fluorescence pattern observed with either of the buffers. Therefore, the assay was carried out in phosphate buffer.

2.4. $\mathrm{H}_{2} \mathrm{O}_{2}$ Determination in Crab Tissues. It was observed that tissues of the crab Scylla serrata contain variable amount of $\mathrm{H}_{2} \mathrm{O}_{2}$ and CAT [13]. Also tissues of $S$. serrata contain other antioxidant enzymes such as SOD and glutathione peroxidase which metabolize $\mathrm{H}_{2} \mathrm{O}_{2}$ [15]. Along with the above reasons, as $S$. serrata is a good model to study several ecophysiological phenomenons [16], tissues of $S$. serrata were chosen for the present study to validate the method of modified $\mathrm{H}_{2} \mathrm{O}_{2}$ determination. Male S. serrata $(65 \pm 5 \mathrm{~g})$ were obtained from the local market of Bhubaneswar, Odisha, India. Gill, hepatopancreas, and muscle tissues were dissected immediately after sacrificing the animals. 20\% tissue homogenates of muscle, gill, and hepatopancreas were prepared in $25 \mathrm{mM}$ PB containing $2 \mathrm{mM}$ EDTA and Triton X-100 (0.1\%, v/v), pH 7.6, using a motor driven glass-Teflon homogenizer at $4^{\circ} \mathrm{C}$. Half of the crude homogenates were immediately precipitated with TCA $(5 \%, w / v)$ and the rest of the halves were treated as the respective control. The volume used for addition of TCA into the sample was replaced with the volume with $25 \mathrm{mM}$ PB for control samples. Both the homogenates were then centrifuged at $10,000 \times \mathrm{g}$ for $10 \mathrm{~min}$ at $4^{\circ} \mathrm{C}$ in dark. The obtained supernatant was neutralized with the required quantity of $6 \mathrm{M} \mathrm{K}_{2} \mathrm{HPO}_{4}\left(214 \mu \mathrm{L} 6 \mathrm{M} \mathrm{K} \mathrm{KPO}_{4} \mathrm{~mL}^{-1}\right.$ of 


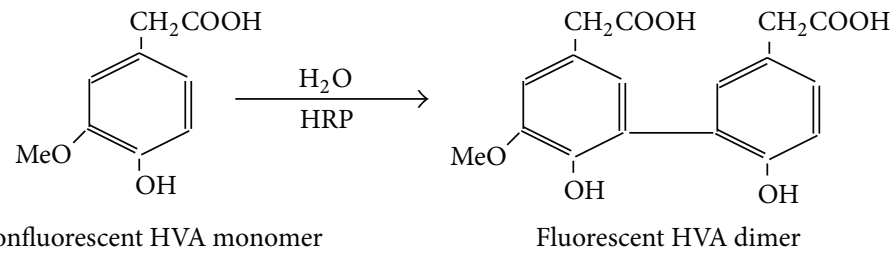

FIGURE 1: Mechanism of fluorescent dimer production of HVA after oxidation by $\mathrm{H}_{2} \mathrm{O}_{2}$ catalyzed by HRP.

sample in 5\% TCA) and its $\mathrm{H}_{2} \mathrm{O}_{2}$ content was determined. The nonprecipitated samples were also subjected to the same procedure except $\mathrm{PB}$ was used in all steps instead of TCA and $\mathrm{K}_{2} \mathrm{HPO}_{4}$. Effort was made to avoid light exposure at each step since $\mathrm{H}_{2} \mathrm{O}_{2}$ is light sensitive. $\mathrm{H}_{2} \mathrm{O}_{2}$ was measured in both the samples and the fluorescence values were then compared. In case of crab hepatopancreas, the required dilution was done before using the samples for $\mathrm{H}_{2} \mathrm{O}_{2}$ content determination. Appropriate blanks [(-sample + HVA + HRP $),(+$ sample + HVA - HRP) and (+sample -HVA + HRP)] were run to check any background fluorescence of the reaction mixtures. In the above step, both TCA precipitated and nonprecipitated samples were used.

2.5. Statistical Analyses. Data are presented as mean ( \pm S.D.) of three samples each having technical triplicates. Student's $t$ test at $P<0.05$ level was used to compare the values between TCA precipitated and control samples. One-way ANOVA followed by Duncan New Multiple range test was performed to validate the statistical difference between different time point groups of either TCA treated or control samples at $P<0.05$.

\section{Results}

3.1. The Assay System. The dose curve was bell shaped when $\mathrm{H}_{2} \mathrm{O}_{2}$ was used in log phase concentrations from $1 \mu \mathrm{M}$ to 10 , $000 \mu \mathrm{M}$ (Figure 2(a)). This broad range of $\mathrm{H}_{2} \mathrm{O}_{2}$ concentration was used to have a broad idea about the linearity of the dose curve of $\mathrm{H}_{2} \mathrm{O}_{2}$ with the given HVA and HRP concentration. Results of the present study reflect that calibration curve of $\mathrm{H}_{2} \mathrm{O}_{2}$ in $2 \mathrm{~mL}$ assay mixture $\left(1-6 \mu \mathrm{M}\right.$ of $\mathrm{H}_{2} \mathrm{O}_{2}, 125 \mathrm{mM}$ $\mathrm{HVA}$, and $0.1 \mathrm{U} \mathrm{mL}^{-1} \mathrm{HRP}$ ) was linear when incubated for $1 \mathrm{~h}$. However, the time required for the saturation of the reaction with the above assay composition appeared to be more than $1 \mathrm{~h}$ (Figures 2(b), 2(c), and 2(d)). Therefore, the actual time needed to have a maximum difference in emission value (in order to confirm the completion of the reaction) between two different concentrations of $\mathrm{H}_{2} \mathrm{O}_{2}(100 \mu \mathrm{M}-200 \mu \mathrm{M})$ was determined. It was observed that around $2 \mathrm{~h}$ was needed to quench maximum number of the $\mathrm{H}_{2} \mathrm{O}_{2}$ molecules present in the reaction mixture with $125 \mu \mathrm{M}$ HVA and $0.1 \mathrm{U} \mathrm{mL}^{-1} \mathrm{HRP}$ (Figures 2(c) and 2(d)). After $2 \mathrm{~h}$ incubation, no significant increase in the emission for both the concentrations of $\mathrm{H}_{2} \mathrm{O}_{2}$ was observed (Figure 2(c)) due to saturation of the assay system.

3.2. Effects of TCA Precipitation on the Assay System. Dose curve of TCA precipitated $\mathrm{H}_{2} \mathrm{O}_{2}(1-16 \mu \mathrm{M})$ followed by neutralization with $\mathrm{K}_{2} \mathrm{HPO}_{4}$ was not only similar but also was almost the same with that of their corresponding control samples (Figure 2(e)). The saturation time for completion of the reaction in the above conditions for $100 \mu \mathrm{M}$ and $200 \mu \mathrm{M}$ $\mathrm{H}_{2} \mathrm{O}_{2}$ in both TCA precipitated and nonprecipitated condition was found to be $2 \mathrm{~h}$ (Figures 2(c) and 2(d)). CAT uses $\mathrm{H}_{2} \mathrm{O}_{2}$ as its substrate. Almost linear decreased emission value was observed when the assay mixtures were preincubated with different concentrations (5-20 U) of catalase enzyme for different (0-20 min) time periods (Figures 3(a), 3(b), and 3(c)). As $\mathrm{H}_{2} \mathrm{O}_{2}$ with CAT after precipitation with TCA did not show further increase in fluorescence value, therefore, it was confirmed that CAT got precipitated with 5\% TCA (Figure 4). The HVA dimer product in both TCA treated and nontreated $\mathrm{H}_{2} \mathrm{O}_{2}$ was found to be stable up to at least $12 \mathrm{~h}$. However, a $10 \%$ loss in fluorescence of the HVA dimer, produced after the end of the reaction was observed after 60 $\mathrm{h}$ than $2 \mathrm{~h}$ (Figure 4). Das et al. [17] described a method in which superoxide radical is produced by photoreduction of riboflavin and subsequently measured by spectrophotometric method. SOD converts superoxide radical to $\mathrm{H}_{2} \mathrm{O}_{2}$. Using the above principles, they implemented the measurement system finally for determination of SOD content in samples. Logically it was expected in the above system that if SOD will be added instead of tissue samples then the produced superoxide radicals can be converted into $\mathrm{H}_{2} \mathrm{O}_{2}$ and then can be measured using the current principle of HVA oxidation method. The results depicted that $\mathrm{H}_{2} \mathrm{O}_{2}$ cannot be measured by this method where light is a precursor for its production such as in superoxide radical generating system by riboflavin reduction method [17] incubated with SOD enzyme (Figure 5).

3.3. Validation of the Method in Biological Samples. The above modification of HVA oxidation method to determine $\mathrm{H}_{2} \mathrm{O}_{2}$ content in samples was tested in a crab model. In TCA treated muscle, gills, and hepatopancreas tissue fractions of the crab S. serrata, a minimum of $2.0,2.2$, and 2.5 folds $(P<0.05)$ higher amount of $\mathrm{H}_{2} \mathrm{O}_{2}$ was observed than TCA non-treated samples (Figure 6).

\section{Discussion}

$\mathrm{H}_{2} \mathrm{O}_{2}$ in tissues is used as a major biomarker in multiple biochemical investigations [1]. $\mathrm{H}_{2} \mathrm{O}_{2}$ mediated production of highly toxic hydroxyl radical has also many biochemical implications [3]. $\mathrm{H}_{2} \mathrm{O}_{2}$ is metabolized in many enzymatic reactions in tissues. Therefore, to quantify the accurate level of $\mathrm{H}_{2} \mathrm{O}_{2}$ in tissues (containing its metabolizing enzymes) using 


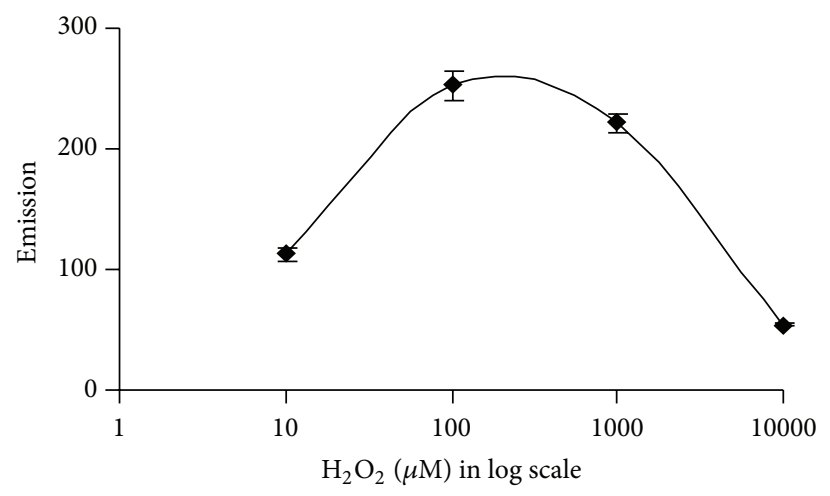

(a)

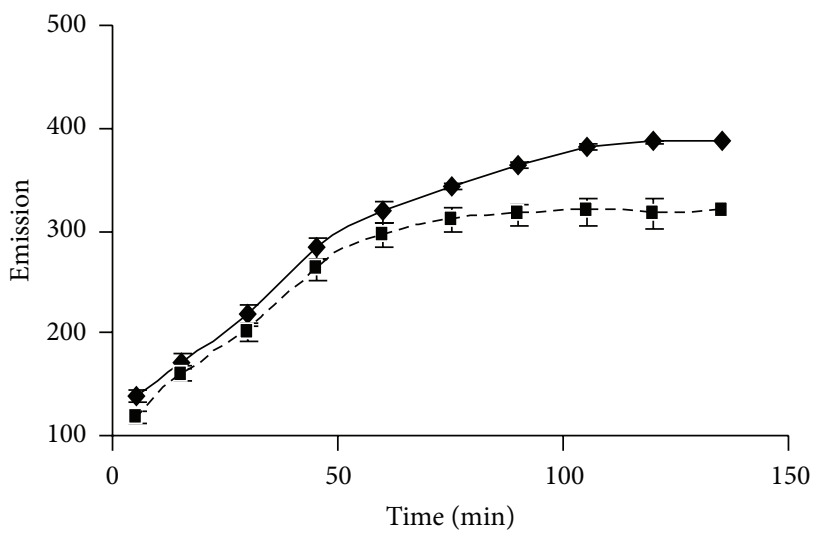

$-200 \mu \mathrm{M}$
$-\square-100 \mu \mathrm{M}$

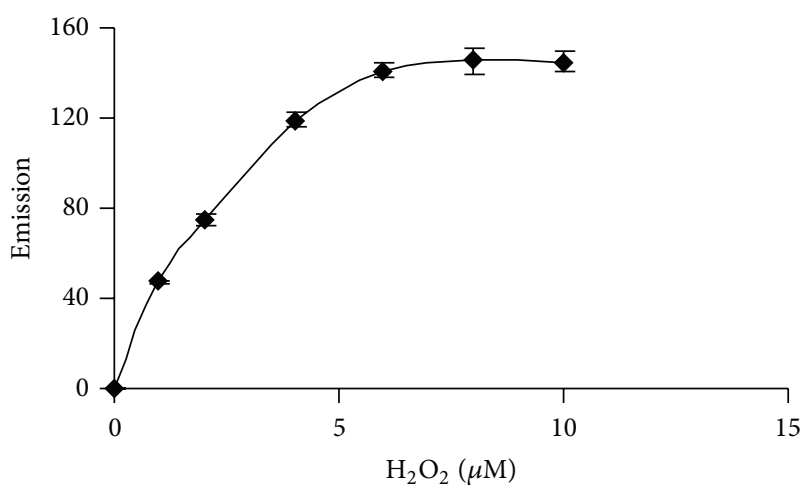

(b)

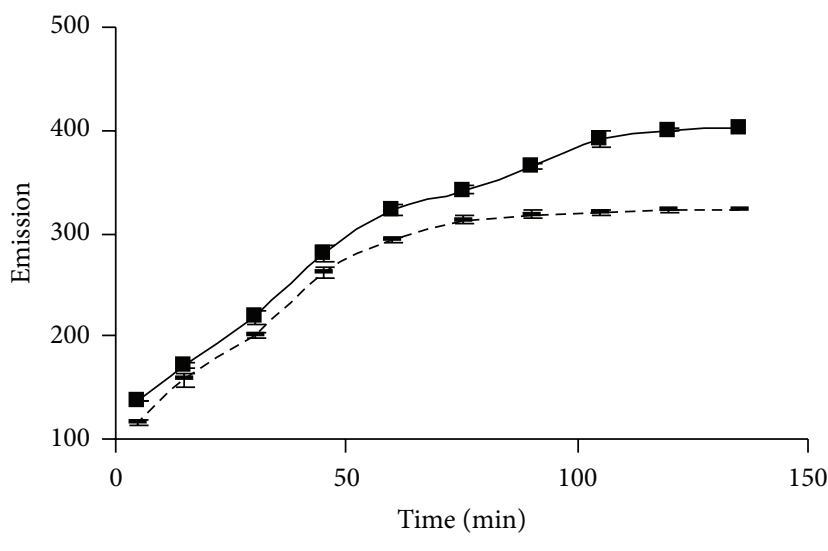

$--100 \mu \mathrm{M}$

$\rightarrow-200 \mu \mathrm{M}$

(c)

(d)

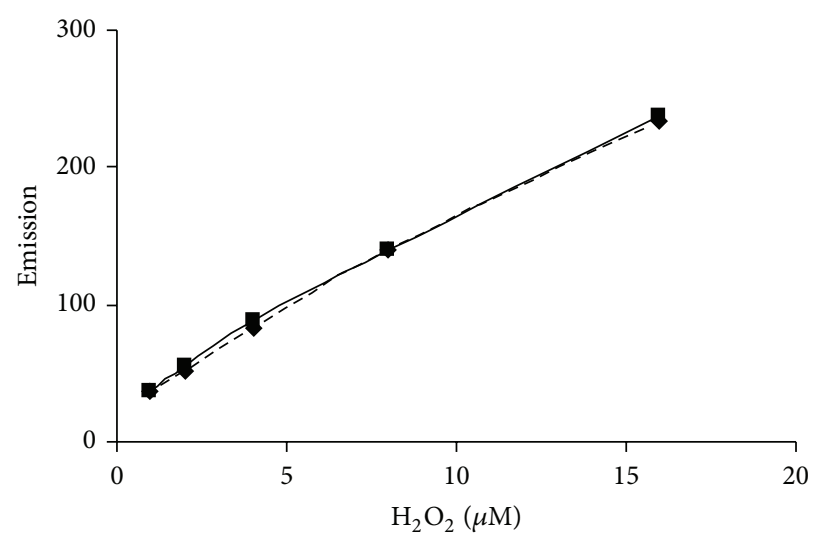

- - Without TCA

- With TCA

(e)

FIGURE 2: Calibration curves of $\mathrm{H}_{2} \mathrm{O}_{2}$ in the assay system. $\mathrm{H}_{2} \mathrm{O}_{2}$ concentration was used in the range of 1 to $1000 \mu \mathrm{M}$ (a) and 1-15 $\mu \mathrm{M}$ (b) with $1 \mathrm{~h}$ incubation of the reaction mixture. Time kinetics $(0-2 \mathrm{~h})$ for completion of reaction for two concentrations of $\mathrm{H}_{2} \mathrm{O}_{2}(100-200 \mu \mathrm{M})$ without (c) and with (d) TCA treatment of $\mathrm{H}_{2} \mathrm{O}_{2}$ followed by neutralization prior to use. Dose curve for $\mathrm{H}_{2} \mathrm{O}_{2}(1-16 \mu \mathrm{M})$ in both TCA treated and nontreated condition with $2 \mathrm{~h}$ incubation of the reaction mixture (e). In all cases $125 \mu \mathrm{M} \mathrm{HVA}$ and $0.1 \mathrm{U} / \mathrm{mL} \mathrm{HRP}$ were used in $2 \mathrm{~mL}$ reaction mixture at $25^{\circ} \mathrm{C}$. 


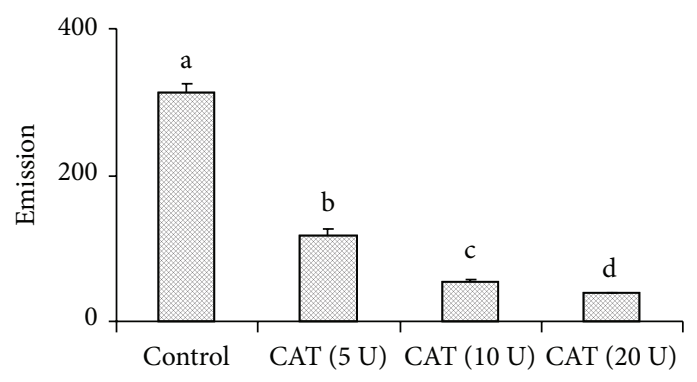

(a)

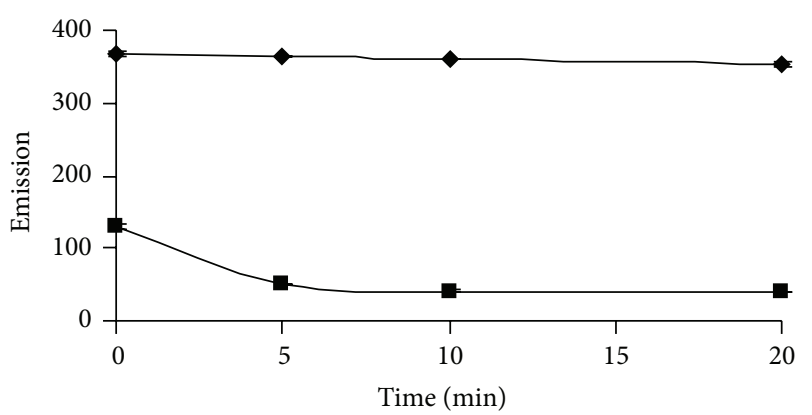

Without CAT

With CAT (b)

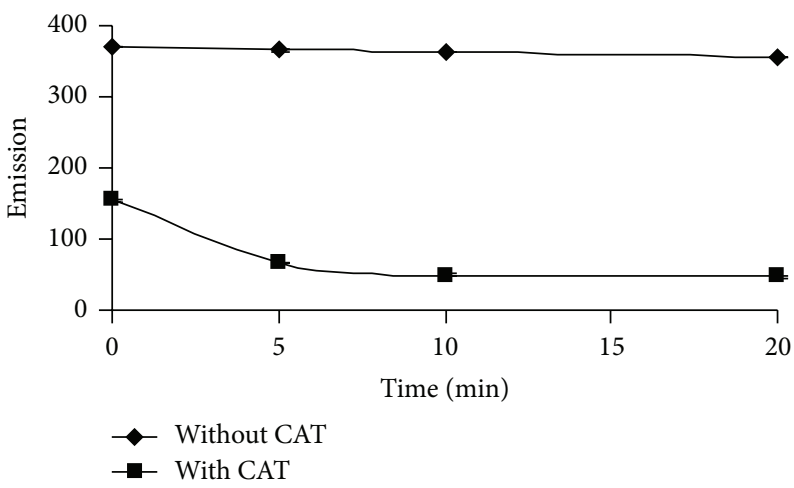

(c)

FIGURE 3: Estimation of $\mathrm{H}_{2} \mathrm{O}_{2}$ in the presence of catalase. (a) $200 \mu \mathrm{M} \mathrm{H}_{2} \mathrm{O}_{2}$ was incubated with different concentrations of CAT for 10 min. Validation of the method with CAT and $200 \mu \mathrm{M} \mathrm{H}_{2} \mathrm{O}_{2}$ treated with (c) or without (b) TCA. TCA treated $\mathrm{H}_{2} \mathrm{O}_{2}$ sample was neutralized with $\mathrm{K}_{2} \mathrm{HPO}_{4}$ before it was incubated with $20 \mathrm{U}$ CAT followed by quantification. Results were the same regardless of using TCA. Different superscripts in Figure 3(a) indicate statistical significance at $P \leq 0.04$.

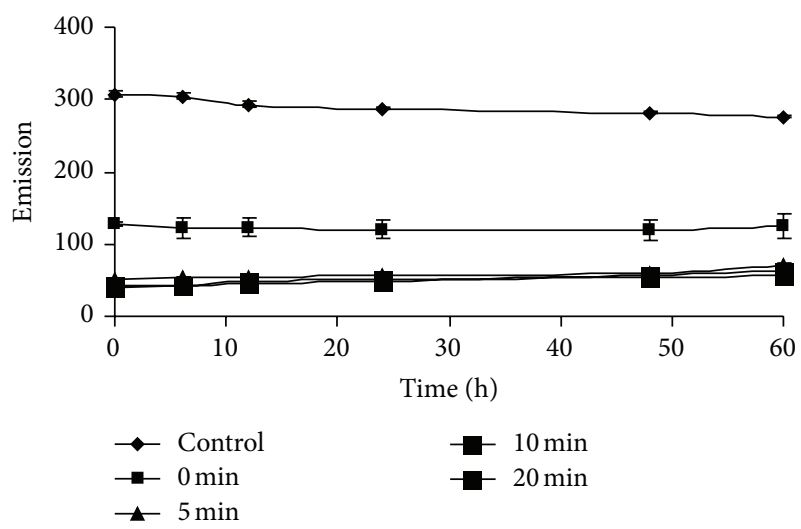

(a)

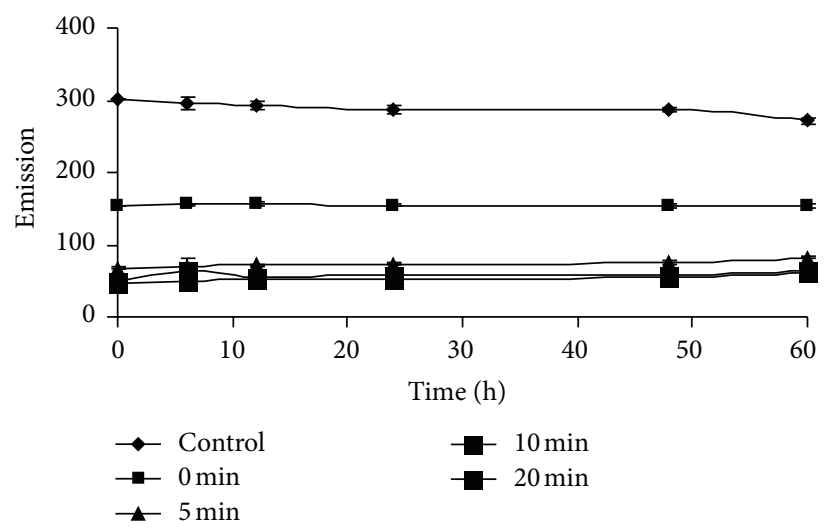

(b)

FIGURE 4: Stability of HVA dimer as reaction product in TCA treated (a) and TCA nontreated (b) $\mathrm{H}_{2} \mathrm{O}_{2}$ sample as a function of time. CAT $(20 \mathrm{U})$ was incubated with the reaction mixture for different time periods $(0-20 \mathrm{~min})$ followed by TCA $(5 \%$, w/v) precipitation, neutralization with $\mathrm{K}_{2} \mathrm{HPO}_{4}$, and $\mathrm{H}_{2} \mathrm{O}_{2}$ quantification in HVA-HRP method.

biochemical methods can be a challenge. A modified method using HVA oxidation principle is proposed to measure the exact $\mathrm{H}_{2} \mathrm{O}_{2}$ level in tissues. Homovanillic acid is a nonfluorophore compound which is converted to a highly fluorescent compound after oxidation in $\mathrm{HRP}-\mathrm{H}_{2} \mathrm{O}_{2}$ system (Figure 1). This principle is used to estimate $\mathrm{H}_{2} \mathrm{O}_{2}$ in biological samples
[14]. In all assays where $\mathrm{H}_{2} \mathrm{O}_{2}$ is quantified by employing HVA-HRP system, the reaction mixture is incubated for different time intervals ranging from $5 \mathrm{~min}$ to $1 \mathrm{~h}[4,6,18]$. Then the final fluorescent products are measured without terminating the reaction. Efforts had also been made to terminate the reaction by increasing the $\mathrm{pH}$ of the reaction 


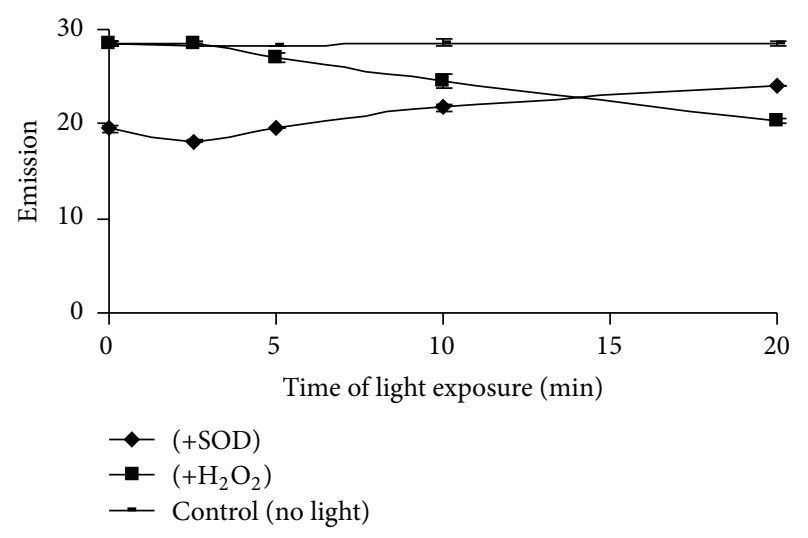

FIGURE 5: Failure of the HRP-HVA method for $\mathrm{H}_{2} \mathrm{O}_{2}$ quantification in light dependent $\mathrm{H}_{2} \mathrm{O}_{2}$ production system. Superoxide radicals were generated in light dependent riboflavin reduction system and were converted to $\mathrm{H}_{2} \mathrm{O}_{2}$ by the enzyme SOD $\left(20 \mathrm{U} \mathrm{mL}^{-1}\right) . \mathrm{H}_{2} \mathrm{O}_{2}$ $(2 \mu \mathrm{M})$ was used as positive control in presence or absence of light.

mixture to alkaline range $(\mathrm{pH}>10)$ before estimating the fluorescent intensity of the samples [18]. In both of the above cases, it seems that, without determining the time kinetics for saturation of the reaction, accurate amount of $\mathrm{H}_{2} \mathrm{O}_{2}$ in the reaction mixture may not be determined. This is because a certain amount of $\mathrm{H}_{2} \mathrm{O}_{2}$ may be retained in the reaction mixture due to insufficient time to end the reaction (at high $\mathrm{pH})$ before it is being completed. Most of the biological samples especially tissue fractions contain several enzymes such as CAT and several peroxidase and oxidase enzymes which can metabolize $\mathrm{H}_{2} \mathrm{O}_{2}$. During tissue fractionation and incubation steps for $\mathrm{H}_{2} \mathrm{O}_{2}$ determination in such samples, the possibility of getting inconsistent result cannot be ruled out. Therefore, the assay system can measure more accurate $\mathrm{H}_{2} \mathrm{O}_{2}$ content in the sample if only the $\mathrm{H}_{2} \mathrm{O}_{2}$ metabolizing enzymes are removed from the reaction mixture and the reaction mixture gets sufficient time period for completion. In this communication, a small but important modification in HVA oxidation method to estimate $\mathrm{H}_{2} \mathrm{O}_{2}$ in biological samples is reported. This was achieved by precipitating tissue fractions with ice cold TCA (5\%) and neutralization with $\mathrm{K}_{2} \mathrm{HPO}_{4}$ followed by $\mathrm{H}_{2} \mathrm{O}_{2}$ quantification. The time kinetics of the reaction to determine the optimum time required to complete the reaction between all $\mathrm{H}_{2} \mathrm{O}_{2}$ and HVA molecules in the system was also investigated.

Decreased florescence values that were observed for $\mathrm{H}_{2} \mathrm{O}_{2}$ samples with CAT treatment suggest the specificity of the reaction by $\mathrm{H}_{2} \mathrm{O}_{2}$ only. Time kinetics study suggests that minimum $2 \mathrm{~h}$ incubation time of assay mixture was required ( 1 to $25 \mu \mathrm{M}$ range of $\mathrm{H}_{2} \mathrm{O}_{2}$ or sample with $125 \mu \mathrm{M}$ HVA and $0.1 \mathrm{U} \mathrm{mL}^{-1} \mathrm{HRP}$ ) to complete the reaction. However, one can reduce the time of incubation by increasing the HRP and HVA concentration $[4,19]$. HVA dimer as the reaction product in both TCA treated and nontreated pure $\mathrm{H}_{2} \mathrm{O}_{2}$ and tissue samples was found to be stable for more than $60 \mathrm{~h}$ with only loss of $10 \%$ of fluorescence intensity. However, up to $12 \mathrm{~h}$, the loss was less than $2 \%$ and statistically was not significant than the value observed after $2 \mathrm{~h}$ incubation. Thus, reaction product can be kept conveniently in the dark for at least half a day for quantification of $\mathrm{H}_{2} \mathrm{O}_{2}$.

An attempt was made to measure superoxide radical (having very low half-life) by employing this method. Light mediated riboflavin reduction method was employed for superoxide generation. SOD enzyme converts superoxide radicals to $\mathrm{H}_{2} \mathrm{O}_{2}$. The above assay mixture that generates superoxide radical under light was incubated with SOD enzyme. It was expected that $\mathrm{H}_{2} \mathrm{O}_{2}$ could be measured and the value could be correlated with the generated superoxide radical level. However, no significant fluorescent value was obtained in the process for $\mathrm{H}_{2} \mathrm{O}_{2}$ in the above system. It may be due to the breakdown of the produced $\mathrm{H}_{2} \mathrm{O}_{2}$ under high fluorescent light.

Finally, $\mathrm{H}_{2} \mathrm{O}_{2}$ content in the tissues of an invertebrate containing most of the $\mathrm{H}_{2} \mathrm{O}_{2}$ metabolizing enzymes (the mud crab S. serrata) was measured. It was observed that around $\geq 2$ folds $\mathrm{H}_{2} \mathrm{O}_{2}$ was lost in muscle, hepatopancreas, and gills of the crab during tissue processing and incubation time for $\mathrm{H}_{2} \mathrm{O}_{2}$ determination. Recently, it is described that activities of CAT and glutathione peroxidase, the two major $\mathrm{H}_{2} \mathrm{O}_{2}$ catalyzing enzymes in this crab, are tissue-specific [20]. This may be the cause for tissue-specific loss of $\mathrm{H}_{2} \mathrm{O}_{2}$ in the crabs during $\mathrm{H}_{2} \mathrm{O}_{2}$ determination without TCA precipitation. Therefore, the loss of $\mathrm{H}_{2} \mathrm{O}_{2}$ during measurement may vary in different organs of an organism and in the same organ of different organisms due to the difference in $\mathrm{H}_{2} \mathrm{O}_{2}$ contents and $\mathrm{H}_{2} \mathrm{O}_{2}$ metabolizing enzymes.

One of the limitations of this method was that tissues were not directly homogenized in acids such as metaphosphoric acid which is used to remove enzymes from tissue fractions. TCA is an aggressive acid and, therefore, homogenization of tissues directly in TCA is not recommended. Neutralization of TCA $(5 \%, w / v)$ treated samples was needed to keep the $\mathrm{pH}$ between 7 and 8 because HRP has optimum activity within this $\mathrm{pH}$ range. Therefore, the exact stoichiometry of the neutralization reaction between TCA $(5 \%, w / v)$ and $\mathrm{K}_{2} \mathrm{HPO}_{4}(6 \mathrm{M})$ was not evaluated. So, the neutralization of TCA treated samples to study the final $\mathrm{pH}$ must be done prior to any assay. The method can also be applied to study other metabolites in tissue fractions where specific enzymes interfere in assaying a particular metabolite. However, before adapting TCA precipitation method to quantify a particular metabolite, its assay system must be checked in similar way with TCA and the pure metabolite. This modification method can be used in multiple studies where tissue $\mathrm{H}_{2} \mathrm{O}_{2}$ level is used as an important index [1]. The optimization of the HVA concentration and HRP activity may be carried out for further optimization of the method. Sometimes, much higher amount $(>1 \mathrm{~mL})$ of both TCA treated and untreated sample showed lower fluorescence values in comparison to the respective lower sample volumes. The reason may be attributed to the artifacts that quench or hinder the HVA dimer production.

It is claimed that phosphate ion or buffer, if used, may interfere in the fluorescence assay system [21]. However, the above authors used phosphate buffer to check the effects of $\mathrm{pH}(7-9.5)$ on the detection system using immobilized peroxidase with a fibre-optic detector. They observed that 


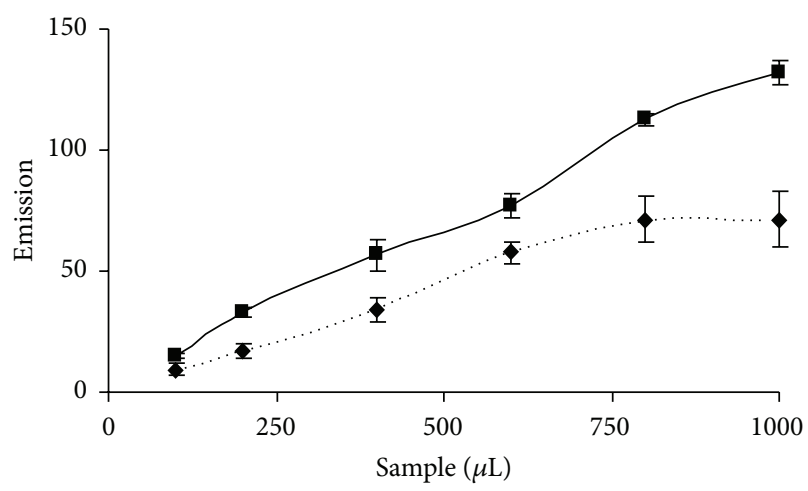

(a)

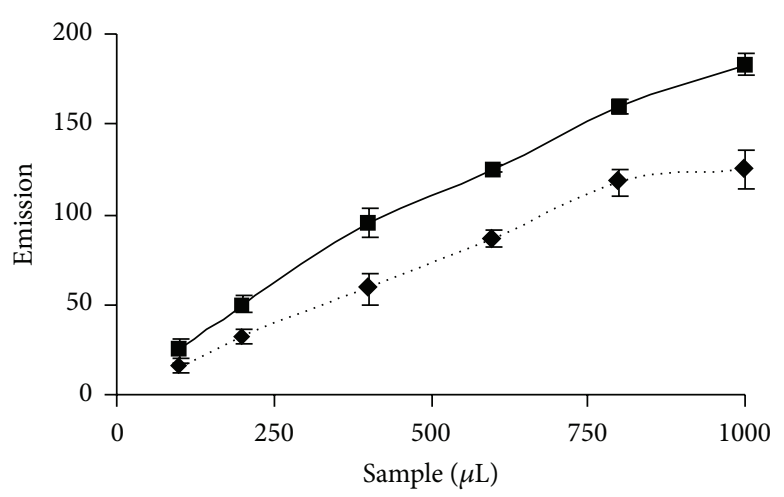

(b)

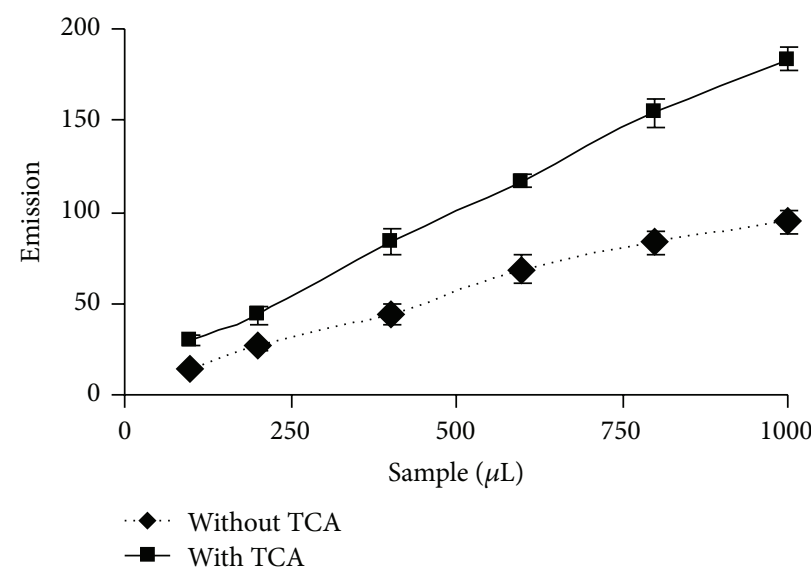

(c)

Figure 6: Determination of $\mathrm{H}_{2} \mathrm{O}_{2}$ in tissue fractions of the mud crab Scylla serrata. In muscle (a), gills (b), and hepatopancreas (c), the fluorescence of the TCA treated samples was almost $\geq 2$ folds higher than its corresponding nontreated sample. Tissue fractions were precipitated immediately after homogenization followed by neutralization with $\mathrm{K}_{2} \mathrm{HPO}_{4}$ and $\mathrm{H}_{2} \mathrm{O}_{2}$ quantification.

the naturalized $\mathrm{pH}$ was the optimum to get the fluorescence signal by the optic sensor. This could be due to the activity optima of immobilized HRP in neutralized $\mathrm{pH}$. Apparently, no reports are available exclusively to check the effects of phosphate ion on the HRP and HVA mediated $\mathrm{H}_{2} \mathrm{O}_{2}$ assay system. However, it seems that there is a very less chance for the interference of phosphate ion on the assay system as no difference was observed in TCA treated and untreated positive controls, that is, pure $\mathrm{H}_{2} \mathrm{O}_{2}$ samples, because, in TCA treated pure $\mathrm{H}_{2} \mathrm{O}_{2}$ samples, high concentrations of phosphate ions would be there since $6 \mathrm{M} \mathrm{K}_{2} \mathrm{HPO}_{4}$ was used to neutralize it. Although higher fluorescence values were observed in the present study with tris buffer than phosphate, it was statistically not significant (data not given). Nevertheless, a negative control by using excess catalase in the tissue sample prior to TCA precipitation would enhance the accuracy of the method. However, no fluorescence was observed in the samples when intentionally the stored (at $4^{\circ} \mathrm{C}$ for 1-2) tissue fractions were used for $\mathrm{H}_{2} \mathrm{O}_{2}$ content measurement (data not given). The reason(s) could be contributed to the $\mathrm{H}_{2} \mathrm{O}_{2}$ scavenging activity of the tissue fractions due to multiple reasons including acceleration of Fenton chemistry and/or utilization of the $\mathrm{H}_{2} \mathrm{O}_{2}$ by the presence of internal catalase and other $\mathrm{H}_{2} \mathrm{O}_{2}$ catabolizing enzymes.
Shirasaka et al. [22] noticed that HRP also can break down lipid hydroperoxides and can suppress peroxidation of polyunsaturated fatty acids in the presence of phenolic antioxidants (in 100-200 $\mu \mathrm{M}$ range) such as quercetin, capsaicin, and $\alpha$-tocopherol but not in presence of the reduced glutathione. Therefore, the presence of the above phenolic antioxidants in $\mu \mathrm{M}$ range to interfere in the HRP mediated HVA dimer production by $\mathrm{H}_{2} \mathrm{O}_{2}$ in crab samples is very low. Also for the above additional function of HRP, it needs a proper stoichiometry between HRP and the phenolic antioxidants (in $\mu \mathrm{M}$ range) in the tissue fractions. Phenolic antioxidants are more specifically observed in plant tissues. On the other hand, the specificity of the HRP mediated HVA dimer production can also be evaluated from the basal level of the fluorescence values that were obtained for the blank (assay mixture having no tissue fractions), from samples having tissue fractions and HVA only, and from positive controls. The specificity of the HRP mediated HVA dimer production by $\mathrm{H}_{2} \mathrm{O}_{2}$ is also reported by several authors $[6,14]$ and, therefore, claiming the interference of the above additional function of HRP in the presently proposed assay system can be forfeited, because, due to the above additional function of HRP, its availability for the assay system would not be nullified; rather it would be a little less. 
TCA precipitates proteins in biological samples. It is concluded that TCA precipitation can be employed to prevent internal loss of $\mathrm{H}_{2} \mathrm{O}_{2}$ during processing of tissue samples in order to measure more accurate tissue $\mathrm{H}_{2} \mathrm{O}_{2}$ content in samples. Further, several samples can be processed simultaneously for $\mathrm{H}_{2} \mathrm{O}_{2}$ determination and the end product conveniently can be measured within $12 \mathrm{~h}$.

\section{Conflict of Interests}

The author declares that there is no conflictof interests regarding the publication of this paper.

\section{Acknowledgments}

Postdoctoral fellowship from University Grants Commission (UGC), New Delhi, India, under Dr. D.S. Kothari PDF scheme (F.4-2/2006 (BSR)/13-853/2013 (BSR) is duly acknowledged. The work was also supported by a fellowship provided by UGC under RFSMS scheme (F.4-3/2006 (XI plan/ BSR/7-173/2007(BSR)). Important suggestions rendered by Professor G.B.N. Chainy during the study are duly acknowledged. Heads, Departments of Zoology and Departments of Biotechnology, Utkal University, India, for providing necessary laboratory facilities are acknowledged.

\section{References}

[1] D. Abele, J. P. Vazquez-Medina, and T. Zenteno-Savin, Oxidative Stress in Aquatic Ecosystems, Blackwell and Wiley, Malden, Mass, USA, 1st edition, 2011.

[2] A. Boveris, N. Oshino, and B. Chance, "The cellular production of hydrogen peroxide," Biochemical Journal, vol. 128, no. 3, pp. 617-630, 1972.

[3] B. Halliwell and J. M. C. Gutteridge, Free Radicals in Biology and Medicine, Oxford University Press, New York, NY, USA, 3rd edition, 2001.

[4] M. Paździoch-Czochra and A. Wideńska, "Spectrofluorimetric determination of hydrogen peroxide scavenging activity," Analytica Chimica Acta, vol. 452, no. 2, pp. 177-184, 2002.

[5] P. E. Hockberger, T. A. Skimina, V. E. Centonze et al., "Activation of flavin-containing oxidases underlies light-induced production of $\mathrm{H}_{2} \mathrm{O}_{2}$ in mammalian cells," Proceedings of the National Academy of Sciences of the United States of America, vol. 96, no. 11, pp. 6255-6260, 1999.

[6] H. Iwai, F. Ishihara, and S. Akihama, "A fluorometric rate assay of peroxidase using the homovanillic acid-o-dianisidine-hydrogen peroxide system," Chemical and Pharmaceutical Bulletin, vol. 31, no. 10, pp. 3579-3582, 1983.

[7] J. D. Lambert, S.-J. Kwon, J. Hong, and C. S. Yang, "Salivary hydrogen peroxide produced by holding or chewing green tea in the oral cavity," Free Radical Research, vol. 41, no. 7, pp. 850-853, 2007.

[8] S. G. Rhee, T.-S. Chang, W. Jeong, and D. Kang, "Methods for detection and measurement of hydrogen peroxide inside and outside of cells," Molecules and Cells, vol. 29, no. 6, pp. 539-549, 2010.

[9] G. Queval, J. Hager, B. Gakière, and G. Noctor, "Why are literature data for $\mathrm{H}_{2} \mathrm{O}_{2}$ contents so variable? A discussion of pot- ential difficulties in the quantitative assay of leaf extracts," Journal of Experimental Botany, vol. 59, no. 2, pp. 135-146, 2008.

[10] D. Banerjee, P. A. Kumar, B. Kumar, U. K. Madhusoodanan, S. Nayak, and J. Jacob, "Determination of absolute hydrogen peroxide concentration by spectrophotometric method," Current Science, vol. 83, no. 10, pp. 1193-1194, 2002.

[11] C. Gay, J. Collins, and J. M. Gebicki, "Hydroperoxide assay with the ferric-xylenol orange complex," Analytical Biochemistry, vol. 273, no. 2, pp. 149-155, 1999.

[12] C. A. Gay and J. M. Gebicki, "Perchloric acid enhances sensitivity and reproducibility of the ferric-xylenol orange peroxide assay," Analytical Biochemistry, vol. 304, no. 1, pp. 42-46, 2002.

[13] B. Paital and G. B. N. Chainy, "Antioxidant defenses and oxidative stress parameters in tissues of mud crab (Scylla serrata) with reference to changing salinity," Comparative Biochemistry and Physiology C, vol. 151, no. 1, pp. 142-151, 2010.

[14] K. Staniek and H. Nohl, " $\mathrm{H}_{2} \mathrm{O}_{2}$ detection from intact mitochondria as a measure for one-electron reduction of dioxygen requires a non-invasive assay system," Biochimica et Biophysica Acta, vol. 1413, no. 2, pp. 70-80, 1999.

[15] B. Paital, Effect of salinity on antioxidant defense system of the mud crab Scylla serrata, a commercially important species from Chilika lagoon [Ph.D. thesis], Department of Zoology, Utkal University, Bhubaneswar, India, 2011.

[16] B. Paital and G. B. N. Chainy, "Effects of salinity on $\mathrm{O}_{2}$ consumption, ROS generation and oxidative stress status of gill mitochondria of the mud crab Scylla serrata," Comparative Biochemistry and Physiology C, vol. 155, no. 2, pp. 228-237, 2012.

[17] K. Das, L. Samanta, and G. B. N. Chainy, "A modified spectrophotometric assay of superoxide dismutase using nitrite formation by superoxide radicals," Indian Journal of Biochemistry and Biophysics, vol. 37, no. 3, pp. 201-204, 2000.

[18] A. Anguelov and M. Chichovska, "Effect of paraquat intoxication and ambroxol treatment on hydrogen peroxide production and lipid peroxidation in selected organs of rat," Veterinarski Arhiv, vol. 74, no. 2, pp. 141-155, 2004.

[19] C. Foppoli, R. Coccia, C. Blarzino, and M. A. Rosei, "Formation of homovanillic acid dimer by enzymatic or Fenton systemcatalysed oxidation," International Journal of Biochemistry and Cell Biology, vol. 32, no. 6, pp. 657-663, 2000.

[20] B. Paital and G. B. N. Chainy, "Seasonal variability of antioxidant biomarkers in mud crabs (Scylla serrata)," Ecotoxicology and Environmental Safety, vol. 87, pp. 33-41, 2013.

[21] F. Wang, F. Schubert, and H. Rinneberg, "A fluorometric rate assay of hydrogen peroxide using immobilized peroxidase with a fibre-optic detector," Sensors and Actuators B-Chemical, vol. 28, no. 1, pp. 3-7, 1995.

[22] N. Shirasaka, H. Ohnishi, K. Sato, R. Miyamoto, T. Terashita, and H. Yoshizumi, "Horseradish peroxidase degrades lipid hydroperoxides and suppresses lipid peroxidation of polyunsaturated fatty acids in the presence of phenolic antioxidants," Journal of Bioscience and Bioengineering, vol. 100, no. 6, pp. 653-656, 2005. 

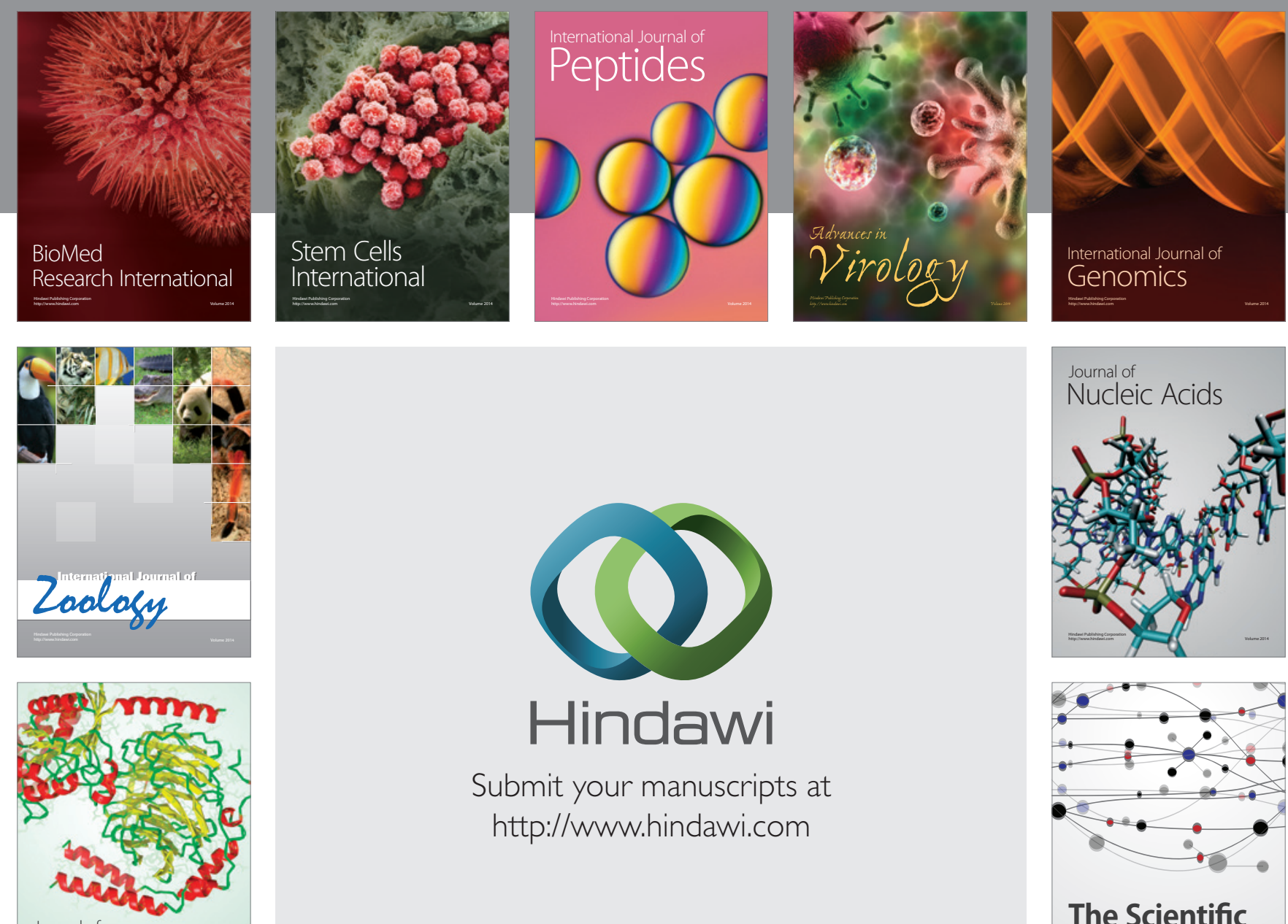

Submit your manuscripts at

http://www.hindawi.com

Journal of
Signal Transduction
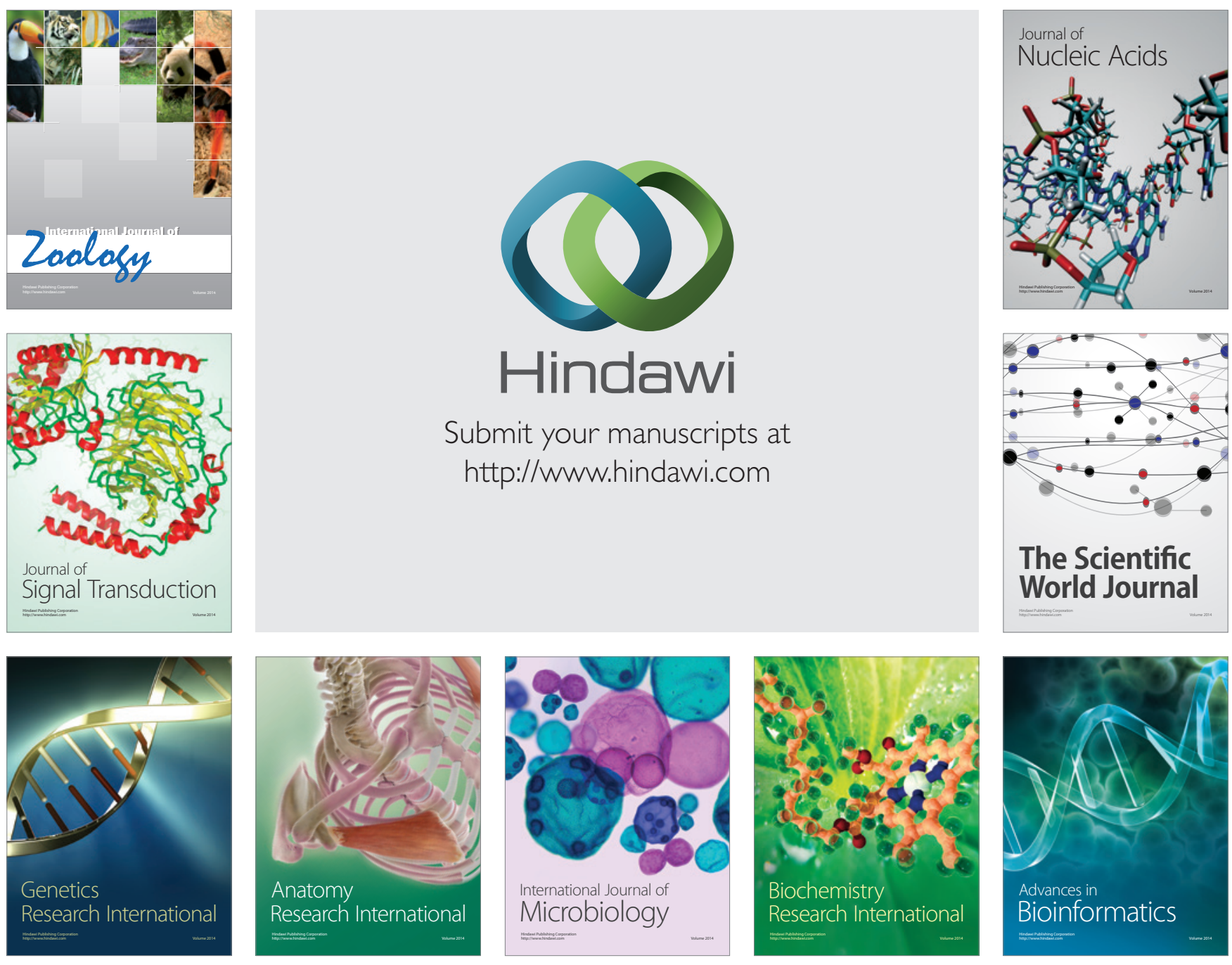

The Scientific World Journal
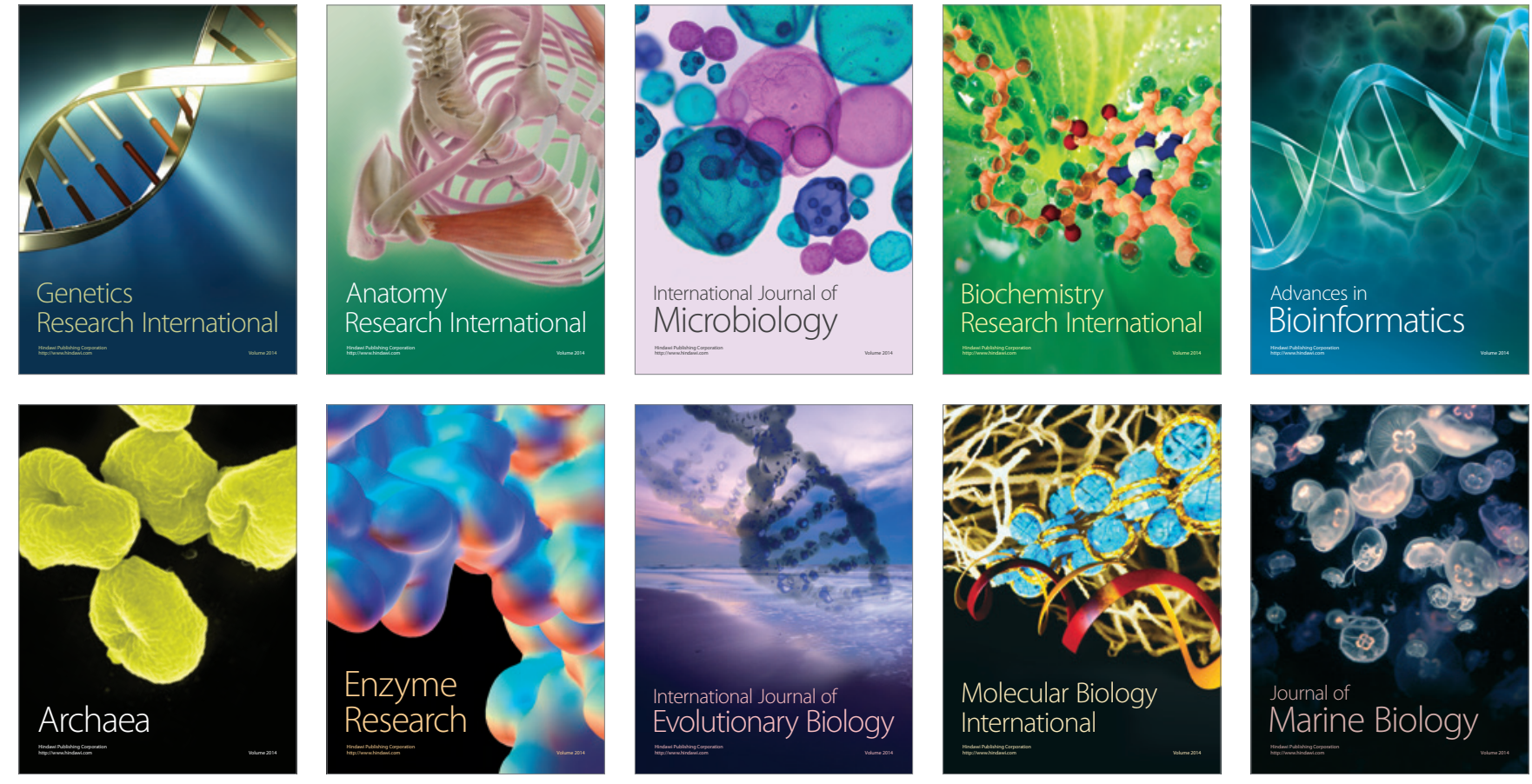